https://doi.org/10.52058/2708-7530-2021-6(12)-112-127

Платонов Олег Ісаакович кандидат економічних наук, докторант кафедри публічного адміністрування Міжрегіональна академія управління персоналом, вул. Фрометівська, 2, м. Київ, 03039, тел.: (050) 316-82-83, еmail: oleg@platonov.od.ua, https://orcid.org/0000-0002-3059-5389

\title{
АНБАНДЛІНГ АТ УКЗАЛІЗНИЦІ ЯК ВЕКТОР ДЕРЖАВНОГО РЕГУЛЮВАННЯ РОЗВИТКУ МУЛЬТИМОДАЛЬНИХ ПЕРЕВЕЗЕНЬ
}

Анотація. У статті акцентовано увагу, що забезпечення інтеграції України в європейську та світову економічні системи в певній мірі означується розвитком мультимодальних перевезень, визначальну роль в якому відіграє Укрзалізниця. Констатовано, що ситуацію, в якій вона наразі опинилась та євроінтеграційні зобов'язання країни за міжнародними угодами в галузі транспорту стали підгрунттям прийняття урядом України рішення про іï структурне реформування. Зазначено, що визначені заходи 3 реформування Укрзалізниці до тепер реалізовано лише частково з причини відсутності чіткої орієнтації на конкретну модель анбандлінгу залізниці. Розглянуто відміні риси кожної з (європейської, американської та гібридної) моделі анбандлінгу залізниць та роль держави у розвитку залізничного транспорту. Коротко проаналізовано етапологію реалізації моделей анбандлінгу залізниць на прикладі європейських країн та США. Наголошено на їх перевагах, які мають бути цікавими Україні при прийнятті рішення щодо вибору найвигіднішої для країни моделі структурного реформування Укрзалізниці. Обгрунтовано доцільність здійснення структурного реформування української залізниці за гібридною моделлю. Наголошено, що для підвищення рівня конкурентоспроможності Укрзалізниці та прискорення розвитку мультимодальних перевезень, заходів, передбачених Законопроектом «Про залізничний транспорт України» від 06.09.2019 р. за №1196-1 недостатньо. Доведено необхідність доповнення Законопроекту №1196-1 нормами 3: регулювання ринку приватної тяги; створення прозорого механізму тарифоутворення; розподілу залізничного тарифу на локомотивну, інфраструктурну та вагонну складову; державної підтримки пасажирських перевезень; створення Залізничного фонду та цільового використання його коштів. Обгрунтвано, що внесення зазначених доповнень до Законопроекту «Про залізничний транспорт України» забезпечить ефективність анбандлінгу Укрзалізниці і відповідно прискорить розвиток мультимодальних перевезень та повноцінність використання мультимода-льного потенціалу України.

Ключові слова: анбандлінг залізниць, державне регулювання, мультимодальні перевезення, структурне реформування залізниць 
Platonov Oleg Isaakovych $\mathrm{PhD}$ (Econ. Interregional Academy of Personnel Management, Frometivska St., 2, Kyiv, 03039, tel.: (050) 316-82-83, e-mail:oleg@platonov.od.ua, https://orcid.org/0000-0002-3059-5389

\title{
UNBANDLING OF JSC UKZALIZNYTSY AS A VECTOR OF STATE REGULATION OF MULTIMODAL TRANSPORTATION DEVELOPMENT
}

\begin{abstract}
The article emphasizes that ensuring the integration of Ukraine into the European and world economic systems is to some extent marked by the development of multimodal transportation, in which Ukrzaliznytsia plays a decisive role. It was stated that the current situation in it and the European integration obligations of the country under international agreements in the field of transport became the basis for the decision of the Government of Ukraine on its structural reform. It is noted that certain measures to reform Ukrzaliznytsia have so far been implemented only in part due to the lack of a clear focus on a specific model of railway unbundling. The distinctive features of each of the (European, American and hybrid) models of railway unbundling and the role of the state in the development of railway transport are considered. The etapology of realization of railway unbundling models on the example of European countries and the USA is briefly analyzed. Emphasis is placed on their advantages, which should be of interest to Ukraine in deciding on the most favorable model for the country of structural reform of Ukrzaliznytsia. The expediency of structural reform of the Ukrainian railway according to the hybrid model is substantiated. It is emphasized that to increase the level of competitiveness of Ukrzaliznytsia and accelerate the development of multimodal transportation, the measures provided by the Bill "On Railway Transport of Ukraine" of 06.09.2019 for №1196-1 are not enough.The necessity of supplementing the Bill №1196-1 with norms on: regulation of the private traction market is proved; creation of a transparent tariff formation mechanism; division of the railway tariff into locomotive, infrastructure and wagon components; state support of passenger transportation; creation of the Railway Fund and targeted use of its funds. It is substantiated that the introduction of these amendments to the Draft Law "On Railway Transport of Ukraine" will ensure the efficiency of unbundling Ukrzaliznytsia and, accordingly, accelerate the development of multimodal transportation and the full use of multimodal potential of Ukraine.
\end{abstract}

Keywords: unbundling of railways, state regulation, multimodal transportation, structural reform of railways

Постановка проблеми. Забезпечення інтеграції України в європейську та світову економічні системи в певній мірі означується розвитком мультимодальних перевезень, визначальну роль в якому відіграє Укрзалізниця. За даними Державної служби статистики в 2020 році територією України залізничним транспортом перевезено понад 425 тис. контейнерів в умовних од. ДФЕ (ДФЕ - двадцятифутовий еквівалент), що 
майже на 11\% вище показника попереднього року [1]. Укрзалізниця планує i надалі розширювати географію й обсяги міжнародних контейнерних перевезень та веде переговори щодо підписання низки договорів про мультимодальні перевезення. Зокрема, наприкінці 2020 р. Укрзалізницею укладено довгострокові угоди про надання послуг 3 компаніями та DHL Global Forwarding, PKP Cargo Connect i BTLC Germany. Домовленість із DHL Global Forwarding передбачає мультимодальне перевезення контейнерних вантажів всією територією України, тобто з наданням комплексу послуг «під ключ». Разом із PKP Cargo Connect здійснюватимуться перевезення контейнерних поїздів із/на станцій залізниць України на станції Польщі 3 подальшим перевезенням одержувачам по всій території ЄС. Домовленість із BTLC Germany передбачає перевезення вантажів у сполученні Китай Україна/СС та в зворотному напрямку і т.д.[2].

Натомість для активізації розвитку мультимодальних перевезень уряд України вбачає за необхідне зробити ряд кроків, серед яких, насамперед, анбандлінг Укрзалізниці, тобто ії структурне реформування.

Аналіз останніх досліджень і публікацій свідчить, що географічне положення України та проходження iï територією міжнародних транспортних коридорів сприяли формуванню в країні вагомого мультимодального потенціалу. За оцінкою інституту «Рендел» Україна за коефіцієнтом транзитності займає перше місце в Свропі. Проте рівень використання мультимодального потенціалу України до тепер лишається досить низьким. I, насамперед, з причини гальмування розвитку вантажних перевезень залізницею. Науковці та практики, зокрема, Дергаусова А., Заболоцька С., Езугбая І., Котик О., Кривінчук Ю., Любохинець Л., Масько А., Пенькова К., Прядко К., Самойдюк М., Січкар Д., Череватенко О., Чеховська М. та ін. вже не перший рік акцентують увагу уряду на потребі структурного реформування залізниці (анбандлінгу залізниці). Однак, наукові дискусії з цього приводу, до тепер не отримали фундаментального та комплексного закріплення, що саме і вимагає на подальше їх дослідження, результати якого, як очікується, стануть поштовхом до впровадження якісно нового інструментарію державного регулювання розвитку мультимодальних перевезень.

Мета статті. Метою статті є філігранне дослідження світового досвіду та українського проекту зі структурного реформування залізниці (анбандлінгу залізниці) та його впливу на розвиток мультимодальних перевезень.

Виклад основного матеріалу. Розуміючи значимість української залізниці у розвитку мультимодальних перевезень, а також ситуацію, в якій наразі вона опинилась та враховуючи євроінтеграційні зобов'язання країни за міжнародними угодами в галузі транспорту, урядом України було прийнято рішення про структурне реформування АТ «Українська залізниця» (далі Укрзалізниця), реалізацію якого розпочато з 2012 р. $з$ введенням в дію Закону України «Про внесенням змін до Закону України «Про залізничний транспорт» від 31.10.2011 p. за №9377 [3]. На першому етапі реформування 
(2012-2013 рр.) передбачалось створення єдиної державної акціонерної компанії і розподіл функцій між нею і державою. На другому етапі реформи (2013-2015 рр.) планувалось створення вертикально інтегрованої виробничотехнологічної системи залізничного транспорту, структурованої за видами діяльності. На третьому етапі (2016-2019 рр.) мало бути ліквідовано перехресне субсидування пасажирських перевезень за рахунок вантажних та передбачалось утворення окремої компанії, яка буде відати пасажирськими перевезеннями [3].

Натомість лише наразі здійснюються спроби щодо реалізації другого етапу структурного реформування Укрзалізниці шляхом ії поділу на окремі операційні підрозділи, а саме: оператора інфраструктури (UZ Infra) перевізників (вантажного - UZ Cargo й пасажирського), а також виробничого підрозділу. Урядовці переконані, що такий підхід дасть змогу забезпечити належну й впорядковану реорганізацію компанії та ефективне управління активами, людськими ресурсами, розподілом фінансових та інших активів і зобов'язань між новими суб'єктами, а також сприятиме реалізації іiі суспільно важливих зобов'язань, зокрема, розвитку мультимодальних перевезень [4].

Для переконання у реалістичності озвучених урядовцями очікувань, здійснимо філігранне дослідження моделей анбандлінгу залізниць, зарекомендованих у світовій практиці як успішних, та моделі структурного реформування Укрзалізниці, запропонованої Міністерством інфраструктури України.

Зазначимо, що у світовій практиці анбандлінг залізниць налічує багато підходів до здійснення перетворень у залізничній галузі, які з однієї сторони мають певну схожість, а з іншої - $\epsilon$ абсолютно протилежними. Схожість названих підходів, насамперед, спостерігається у залученні приватного капіталу в залізничну галузь i впровадженні конкуренції як в інфраструктурній, так і в перевізній діяльності. Розбіжності ж полягають у вертикальній організації функціонування залізниць, починаючи від вертикально інтегрованих залізничних компаній в Північній Америці до впровадження вертикального розділення в країнах Свропи [5, с.3].

Тож, виходячи 3 існуючих підходів до структурного реформування залізниць, у світовій практиці сформувались наступні моделі їх анбандлінгу:

модель вертикального розділу (європейську), за якої передбачається інституційний розділ, тобто повне організаційне виокремлення управляючого інфраструктурою i компаній, що здійснюють залізничні перевезення (вантажні та пасажирські);

модель вертикально-інтегрованого розділу (американську), за якої структурні підрозділи залізниці (крім управління перевезеннями та управління інфраструктурою) управляються 3 різних центрів прийняття рішень та мають власні баланси, однак не є самостійними юридичними особами;

гібридна (холдингова) модель, за якої всі підприємства галузі (юридично незалежні та з окремими балансами) трансформуються в єдиний холдинг [5, с.2]. 
Щодо європейської моделі зазначимо, що першою країною, яка здійснила анбандлінг залізниці стала Великобританія. Маючи на меті зниження надмірного фінансового навантаження на державний бюджет та ліквідацію громіздкої структури управління галуззю, урядом країни у 1994 році було обрано модель вертикального розділення залізниці, схематичне зображення етапології реалізації якої подано на рис.1 [5, с.4].

Досвід британського анбандлінгу залізниць безперечно заслуговує на увагу, оскільки довів те, що приватизація - це необхідна умова, але недостатня для досягнення позитивних результатів реформ. Не менше значимою виявилась i економічна незалежність, тобто відсутність державного втручання в роботу галузі. Тому структурна реформа залізниці Великобританії не забезпечила проблему додаткового залучення інвестицій. Саме тому контроль за вантажними перевезеннями і перейшов до іноземних, насамперед, американських компаній [6].

\begin{tabular}{|c|c|}
\hline \multirow{5}{*}{$\begin{array}{l}\text { Модель } \\
\text { анбандлінгу } \\
\text { залізниці } \\
\text { Великобрита- } \\
\text { нії }\end{array}$} & $\begin{array}{l}\text { Виокремлення державної компанії «Railtrack», що повністю володіє } \\
\text { інфраструктурою }\end{array}$ \\
\hline & Створення адміністрації з вантажних залізничних перевезень \\
\hline & $\begin{array}{l}\text { Поділ відповідальності між } 6 \text { операторами вантажних перевезень, } \\
\text { п’ять з яких придбано British, Welsh \& Scottish Railways (EWS) }\end{array}$ \\
\hline & $\begin{array}{l}\text { Створення OPRAF - адміністрації з пасажирських залізничних } \\
\text { франшиз }\end{array}$ \\
\hline & $\begin{array}{l}\text { Поділ між } 25 \text { компаніями-операторами } \\
\text { пасажирські перевезення }\end{array}$ \\
\hline
\end{tabular}

Pис. 1. Етапологія анбандлінгу залізниці Великобританії [6]

При виборі найбільш виправданої моделі анбандлінгу залізниці України, не менш цікавим $\epsilon$ i досвід Німеччини, урядом якої 3 метою створення єдиної транспортної мережі залізниць колишньої НДР, починаючи з 1994 року було розпочато поетапний анбандлінг залізниць:

- на першому emani шляхом злиття двох державних підприємств «Deutsche Bundesbahn» та «Deutsche Reichsbahn» створено холдинг «Deutsche Bahn AG (DV AG)» зі 100\% приналежністю акцій державі;

- на другому emani для управління залізничною інфраструктурою та залізничними станціями від компаній залізничного зв'язку, а саме Railon Deutschland AG (вантажних перевезень), DB Regio AG (пасажирських перевезень на короткі відстані) та DB Fernverkehr AG (пасажирських перевезень на великі відстані) відокремлено засновані компанії «DB Netz $\mathrm{AG} »$ та «DB Station\&Service AG»[7, с.82]; 
- на третьому етапі структурного реформування залізниці, проведено часткову приватизацію «Deutsche Bahn AG», яка передбачала створення приватної компанії «DB Mobility Logistics AG» та ін;

- на четвертому етапі здійснено регіоналізацію місцевих перевезень та муніципалітетами створено компаній, які здійснюють вантажні та пасажирські перевезення до мережі магістралі (рис. 2).

Саме у такий спосіб Німеччина здійснила анбандлінг залізниці та виконала свої зобов'язання перед СС щодо відмежування надання послуг із залізничних перевезень від управління залізничною інфраструктурою [5, с.6].

Однак, не дивлячись на певні успіхи анбандлінгу залізниць Великобританії та Німеччини, однією з найбільш лібералізованих залізниць в Свропі за оцінкою Європейської Комісії визнано залізницю Швеції, а модель iii анбандлінгу - зразковим прикладом реформування залізниць країн СС.

Модель
$\begin{aligned} & \text { aнбандлінгу } \\ & \text { залізниці } \\ & \text { Німеччини }\end{aligned}$

\section{Pис. 2. Етапологія анбандлінгу залізниці Німеччини [5]}

Перший найбільш значимий етап анбандлінгу залізниць Швеції (1988 2001 рр.) розпочався 3 вертикально-інтегрованого розділення державних залізничних активів та децентралізації регіональних перевезень, під час якого відбувся розділ активів залізниці між «Національною залізничною адміністрацією» (шведською Banverket), яка відповідала за інвестиції та утримання інфраструктури, і компанією Шведські залізниці (шведською Statens Järnvägar або SJ), яка відповідала за перевезення та контролювала диспетчерську службу [8].

Проте вже на другому етапі структурного реформування залізниці Швеції, що розпочався з 2001 р. урядом країни було прийнято рішення щодо зміни моделі анбандлінгу залізниці та здійснено перехід до вертикальної моделі, під час реалізації якої SJ було розділено на Business Administration SJ та сім окремих компаній (рис. 3), з яких три, а саме Jernhucen (з управління інфраструктурою та залізничними станціями), SJ AB (оператор пасажирських перевезень) та Green Cargo (оператор вантажних перевезень) до тепер належать уряду Швеції. Решта компаній приватизовано і наразі вони надають послуги, зокрема, EuroMaint - з технічного обслуговування поїздів, SweMaint 
- 3 управління безпекою перевезень, TraffiCare - зі стивідорних послуг терміналів та Unigrid - послуг з інформатизації тощо.

Відмінною рисою анбандлінгу залізниці Швеції варто визнати i поступове відкриття урядом країни вільного доступу до ринку залізничних перевезень. Зокрема, з 2007 р було впроваджено відкритий доступ до мережі нічним пасажирським поїздам та чартерам, з 2009 р. - впроваджено вільний доступ до залізничної мережі по суботах і неділях, а 32010 р. - запущено вільний доступ протягом тижня. При цьому всі функції Banverket були передані Шведській транспортній адміністрації (Trafikverket), підпорядкованій парламенту і уряду [8].

Таким чином, відмінною рисою анбандлінгу залізниці Швеції є його трансформація від вертикально інтегрованого до повного вертикального розділу 3 наданням рівноправного доступу для усіх учасників ринку перевезень.

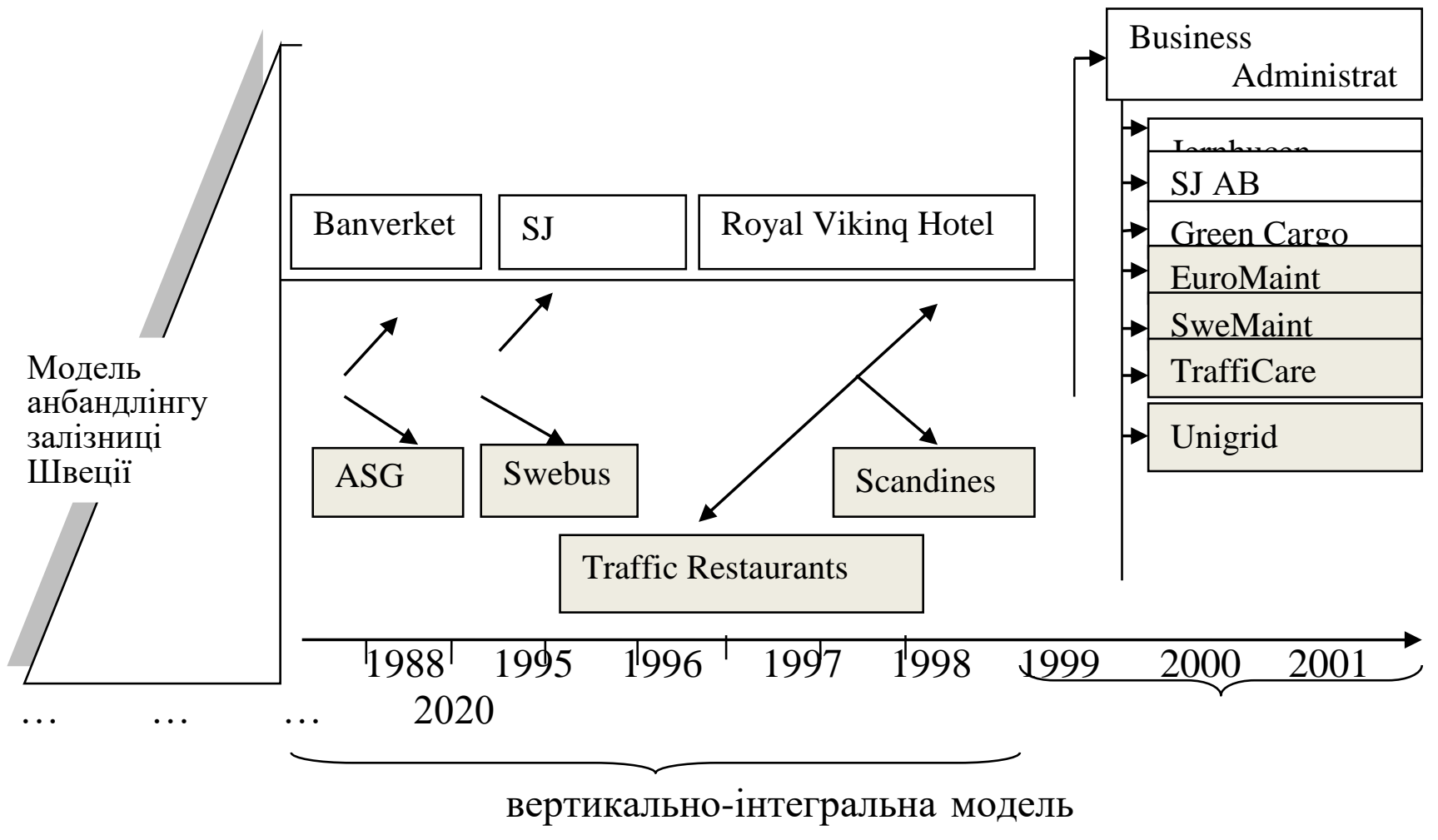

вертикальна

$$
\text { - державна власність; }
$$$$
\text { - приватна власність }
$$

Рис. 3. Етапологія анбандлінгу залізнищі Швеції [8]

В Швейцарії, на відміну від попередньо розглянутих країн, анбандлінг залізниць поєднував у собі риси німецьких та англійських реформ. Зокрема, на початку структурного реформування залізниці уряд країни не вважав за доцільне здійснювати розмежування інфраструктури та перевезень i висловлювався досить негативно щодо приватизації. Натомість з 1999 року Швейцарські федеральні залізниці були виведені з-під керування 
швейцарського уряду та перетворені в особливе акціонерне товариство відкритого типу SBB-CFF-FFS (нiм. Schweizerische Bundesbahnen SBB) зі $100 \%$ власністю держави [5].

3 часом, переконавшись в успішності світового досвіду з анбандлінгу залізниць, урядом Швейцарії, починаючи з 2009 року було прийнято рішення та розпочато структурне реформування залізниці за європейською моделлю, за якою здійснено поділ $S B B-C F F-F F S$ на служби:

- вантажних перевезень;

- пасажирських перевезень;

- управління та ремонту залізничних ліній;

- управління нерухомим майном, що перебуває у власності товариства.

Окрім перелічених служб у «вертикалі» залізниць Швейцарії було виокремлено службу електропостачання, а саме 6 електростанцій, які попередньо входили до складу компанії $S B B-C F F-F F S$. Тож, схематичне зображення етапології анбандлінгу залізниці Швейцарії набуло наступного вигляду (рис. 4).

Щодо структурного реформування залізниці Франції, зазначимо, що створена в 1937 році монополія Національної спілки залізниці Франції «Société Nationale des Chemins de fer Français» (далі - SNCF) проіснувала до 1997 року.

\begin{tabular}{|c|c|}
\hline \multirow{4}{*}{$\begin{array}{l}\text { Модель } \\
\text { анбандлінгу } \\
\text { залізниці } \\
\text { Швейцарії } \\
\text { / }\end{array}$} & $\begin{array}{l}\text { Акціонування залізниці (створення } S B B-C F F-F F S \text { ) із } 100 \% \text { власністю } \\
\text { держави }\end{array}$ \\
\hline & $\begin{array}{l}\text { Розподил на компан1ю 1нфраструктури та експлуатацийн1й компан1ї } \\
\text { операторів }\end{array}$ \\
\hline & $\begin{array}{l}\text { Виокремлення компаній з управління та ремонту залізничних ліній та } \\
\text { компаній } 3 \text { управління нерухомим майном, що перебуває у власності } \\
\text { товариства }\end{array}$ \\
\hline & $\begin{array}{l}\text { Управління } 6 \text { електростанціями, що забезпечують рух залізничного } \\
\text { транспорту }\end{array}$ \\
\hline
\end{tabular}

Рис. 4. Етапологія анбандлінгу залізнищі Швейщарії [5]

3 прийняттям у 1997 році закону про реформування залізниць Франції, було утворено нову структуру - Залізничну мережу Франції (RFF), яка стала власником залізничної мережі. Проте функції управлінням рухом залишились за державною залізничною компанією SNCF - Національною спілкою залізниць Франції [6]. Натомість з внесенням у 2014 р. змін до Транспортного кодексу Франції було розпочато анбандлінг залізниці за гібридною моделлю, тобто шляхом створення державної групи компаній, до якої увійшла SNCF, як материнська компанія, відповідальна за стратегічне управління залізницею та 5-ть дочерних компанії: SNCF Réseau, Rail Logistics Europe, SNCF Voyageurs, Geodis тa Keolis [9]. 
Тож, схематичне зображення етапології гібридної моделі анбандлінгу залізниці Франції набуло наступного вигляду (рис. 5).

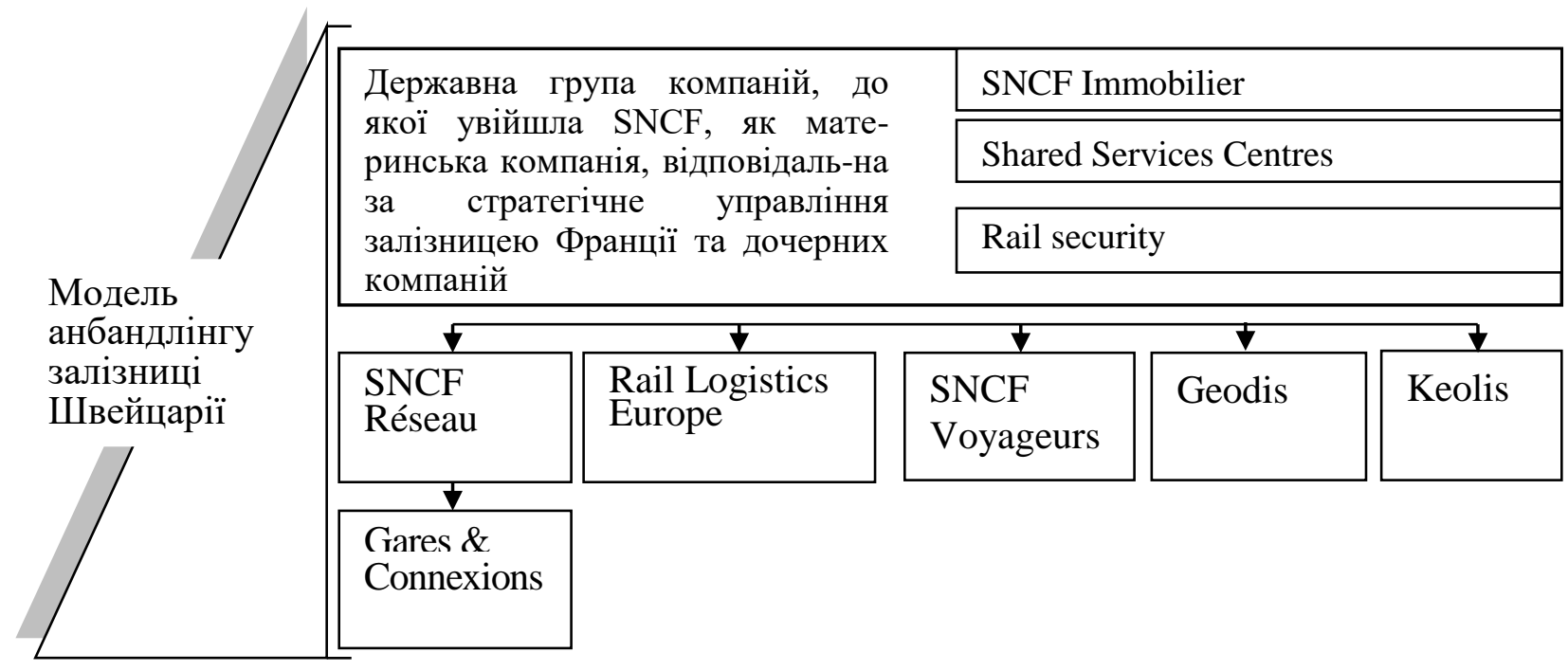

Puc. 5. Етапологія анбандлінгу залізниці Франщії [9]

Дочерну компанію SNCF Réseau було створено з приєднанням власника мережі Réseau Ferré de France (RFF) до SNCF Infra та менеджера по трафіку Direction de la Circulation Ferroviaire (DCF). Наразі SNCF Réseau контролює французьку залізничну мережу і виступає в якості єдиного менеджера залізничної інфраструктури, спрямовуючи свою діяльність на:

забезпечення доступу до інфраструктури залізничної мережі Франції, включаючи розподіл пропускної здатності i встановлення плати за інфраструктуру;

управління мережевим трафіком;

обслуговування і оновлення інфраструктури;

розширення і розвиток мережі з акцентом на загальну ефективність $\mathrm{i}$ оптимальну вартість [9].

На компанію SNCF Gares \& Connexions, що перебуває у підпорядкуванні SNCF Réseau покладено повну відповідальність за стан та експлуатацію залізничних станцій Франції.

Компанія Rail Logistics Europe займається залізничними та мультимодальними вантажними перевезеннями, контролює залізничні перевезення і логістичні операції в Свропі і по всьому світу, надає клієнтам послуги 3 перевезень «від дверей до дверей» для всіх типів вантажів під п'ятьма брендами: SNCF Fret, VIIA, Captrain, Naviland Cargo i Forwardis.

Компанія SNCF Voyageurs в свою чергу є оператором пасажирських перевезень (на далекі відстані) та надає пасажирам послуги 3 транспортування «від дверей до дверей», що відповідають їх потребам 3 точки зору пропозиції, вартості та якості послуг. 
Geodis спеціалізується на логістиці повсякденних пасажирських перевезень (на короткі відстані). Keolis $\epsilon$ приватним оператором громадського транспорту.

Саме у такий спосіб Франція здійснила анбандлінг залізниці та виконала свої зобов'язання перед СС щодо структурного реформування залізниці [9].

Структурне реформування залізниці у Польщі було розпочато в 1991 р. 3 анбандлінгу залізниці на керуючу інфраструктуру та перевізника, що дозволило, насамперед, розділити горизонти відповідальності. В 1998 році Сейм прийняв новий статут про залізницю, внаслідок чого з'явилась нова структура: мереж та ремонтного господарства, пасажирських перевезень, товарних перевезень, а також підрозділи нерухомості, електроенергетики, енергетики, служби управління заробітної плати. На початку двохтисячних було створено нову акціонерну структуру Польську державну залізницю (Polskie Koleje Państwowe) (далі - РКР), яку пізніше було реорганізовано в акціонерне товариство 3 холдинговою структурою управління відокремленими дочірніми компаніями: вантажним i пасажирським операторами, операторами інфраструктури, тяги та інших видів діяльності [10]. Однак неефективне державне управління дочірніми компаніями, незбалансоване боргове навантаження не дали змогу покращити фінансовий результат залізниці. Тож, РКР у 2005 та 2009-2011 рр. розпочала корпоративні реформи, а саме запровадження нових правил внутрішніх процедур у всіх дочірніх структурах (процедури закупівель, підписання контрактів, уникнення конфлікту інтересів), програми зниження витрат, стратегії для кожної дочірньої структури, централізований внутрішній аудит та MBO (Management by Objectives) для нагляду за дочірніми компаніями [10].

Варто визнати, що Польща пішла далі, ніж Німеччина, у плані лібералізації ринку, дозволивши часткову приватизацію своїх дочірніх структур, серед яких були вдалі кейси, як-от: вихід на IPO з ключовим активом - PKP Cargo S.A. (вантажоперевезення) при збереженні контрольного пакету в руках PKP; приватизація PKP Informatyka, а також енергетичної філії РКР Energetyka [11]. Таким чином, ринок залізничних перевезень у Польщі частково дерегульовано (рис. 6). 
Створення AT «Polskie Koleje Państwowe» (100\% акцій належить державі)

Реорганізовано АТ «РКР» в АТ з холдинговою структурою управління та відокремленими дочірніми компаніями: вантажним i пасажирським операторами, операторами інфраструктури, тяги та інших видів діяльності

Модель анбандлінгу залізниці Польщі

Приватизація РКP Informatyka, a також енергетичної філії РКР Energetyka

Часткова дерегуляція ринку залізничних перевезень

Pис. 6. Етапологія анбандлінгу залізнищі Польщзі [11]

На увагу заслуговує і досвід анбандлінгу залізниці США. У 1887 р в США був прийнятий Міжштатний транспортний закон, відповідно до якого залізничні перевезення вантажів перебували під жорстким державним контролем федерального уряду США в особі Комітету 3 межштатной транспорту і торгівлі. Однак, на жаль, досить активна турбота держави призвела до того, що до 1970 р. галузь залізничних вантажних перевезень США виявилась на межі розорення. Порятунком для залізниць стали прийняті Конгресом Закон про стимулювання залізничної галузі та реформу регулювання (Railroad Revitalization and Regulatory Reform Act of 1976), так званий Закон «чотирьох R» та Закон Стеггерса про залізниці (Staggers Rail Act of 1980), які надали залізничним перевізникам велику свободу в процесі ціноутворення, послабили механізми встановлення тарифів, державного контролю за виходом на ринок нових компаній тощо [12].

3 послабленням державного регулювання у сфері залізничних перевезень, прибутковість галузі значно зросла, однак досі перебуває на досить низькому рівні [12].

Таким чином, за результатами дослідження встановлено, що кожна 3 розглянутих моделей анбандлінгу залізниць має певні відмінності. Відмінність анбандлінгу залізниць в європейських країнах полягає в тому, що поряд 3 приватними компаніями успішно «живуть» державні, в тому числі вантажні: PKP Cargo (Польща), DB Cargo (Німеччина), SNCF Fret, Captrain (Франція), Rail Cargo Hungaria (Угорщина), ZSSK Cargo (Словаччина). Вони займають значну частину ринку залізничних перевезень [13]. Відмінність же анбандлінгу залізниць США полягає в повній дерегуляції ринку залізничних перевезень, тобто в повному скасуванні державного регулювання галузі. Однак їх об'єднує прагнення посилити позицій залізничного транспорту у розвитку мультимодальних перевезень.

Здійснюючи ж структурне реформування української залізниці, насамперед, варто враховувати специфіку даного сектора економіки (великі відстані, значні обсяги перевезень тощо) та, як на наш погляд, орієнтуватись на гібридну (холдингову) модель анбандлінгу. 
Зазначимо, що в Україні наразі відсутній розподіл функцій власності і функцій регулювання Укрзалізниці (обидві нині знаходяться під контролем Мінінфраструктури), що призводить до конфлікту інтересів у галузі та неефективності регулювання: 3 одного боку, регулятор повинен забезпечувати запровадження конкуренції, підвищення добробуту населення шляхом установлення якомога нижчих тарифів, контролю якості надання послуг, 3 іншого - будучи розпорядником активів, Мінінфраструктури зацікавлене у зростанні дивідендів, а отже, підвищенні цін чи зниженні витрат, у тому числі за рахунок якості, збереженні власності на максимальну кількість активів у галузі (як джерел отримання прибутку), а не їх виведенні $з$ природної монополії і приватизації. Модель ринку залізничних перевезень повинна передбачити повне організаційне і фінансове розділення перевізника та оператора інфраструктури, що, своєю чергою, гарантуватиме справедливий доступ перевізників до інфраструктури [14, с.31].

Зокрема, за Законопроектом «Про залізничний транспорт України»від 06.09.2019 p. за №1196-1 [15] передбачається наступна етапологія анбандлінгу Укрзалізниці (рис.7):

Розподіл Укрзалізниці на оператора інфраструктури (UZ Infra) та перевізників (вантажного - UZ Cargo й пасажирського), а також створення виробничого підрозділу

Модель реформування залізниці України

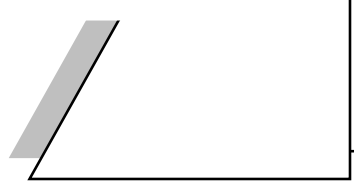

Утворення незалежного регулятора у сфері транспорту - Національної комісії з державне регулювання у сфері транспорту

Припинення перехресного субсидіювання, запровадження вільних тарифів на перевезення

Створення державної спеціалізованої експертної установи 3 технічного розслідування пригод на транспорті

Pис. 7. Етапологія анбандлінгу залізниці України за Проектом 1196-1 [15]

Основою бізнес-вертикалі вантажних перевезень Укрзалізниці має стати новостворений вантажний перевізник UZ Cargo 3 необхідними для безперебій-ної роботи активами, додатковим функціоналом - Центр транспортного сервісу «Ліски», Рефрижераторна вагонна компанія та Центр транспортної логістики. UZcargo отримає в розпорядження локомотиви й вагони, які зараз перебувають у віданні регіональних філій, і зможе повністю вибудувати інтегровану вертикаль. Інші активи будуть віднесені до інфраструктурної вертикалі. Непрофільні активи (медзаклади, санаторії, спортивні споруди) будуть виставлені на продаж або передані у концесію [16].

Тож, наразі не створюються окремі юридичні особи, здійснюється лише суто структурна реорганізація щоб функціонально сформувати вертикаль 3 ефективною моделлю управління. Укрзалізниця ж має бути, насамперед, комерційною, мати незалежність та достатню кількість ресурсів щоб бути конкурентоспроможною, а отже, перелічених заходів для ефективного 
реформування ринку залізничних перевезень недостатньо. Для успішної реформи корпоративного управління Укрзалізниці необхідна чітка та послідовна візія, а також ефективне управління [17]. Тож, Законопроект №1196-1 потребує на доповнення, зокрема, статтями, які передбачатимуть:

- механізм регулювання ринку приватної тяги;

- прозорий механізм тарифоутворення, модифікований шляхом розподілу залізничного тарифу на локомотивну, інфраструктурну та вагонну складову;

- механізм фінансування пасажирських перевезень;

- механізм створення Залізничного фонду та цільового використання його коштів. Наразі Укрзалізниця для перевезення вантажів і пасажирів використовує близько 330 тис. тон дизельного палива в рік, в ціну якого входить акциз, а це близько 1,5 млрд. на рік. Ці кошти з залізничного фонду необхідно направити на утримання залізничної інфраструктури, що дозволить створити здорову конкуренцію між різними видами транспорту, від чого виграє і споживач, і держава [18].

А отже, модель реформування Укрзалізниці має здійснюватись за наступною схемою (рис.8):

\begin{tabular}{|c|}
\hline $\begin{array}{l}\text { Розподіл Укрзалізниці на оператора інфраструктури (UZ Infra) та } \\
\text { перевізників (вантажного - UZ Cargo й пасажирського), а також } \\
\text { створення виробничого підрозділу }\end{array}$ \\
\hline Відкриття ринку приватної тяги \\
\hline Прозора системи тарифоутворення \\
\hline $\begin{array}{l}\text { Утворення незалежного регулятора у сфері транспорту - Національної } \\
\text { комісії з державне регулювання у сфері транспорту }\end{array}$ \\
\hline $\begin{array}{l}\text { Припинення перехресного субсидіювання, запровадження вільних } \\
\text { тарифів на перевезення }\end{array}$ \\
\hline $\begin{array}{l}\text { Створення державної спеціалізованої експертної установи з технічного } \\
\text { розслідування пригод на транспорті }\end{array}$ \\
\hline Створення Залізничного фонду \\
\hline
\end{tabular}

Puс. 8. Запропонована етапологія анбандлінгу залізниці України

Висновки. Таким чином, за результатами дослідження встановлено відмінності кожної 3 розглянутих моделей анбандлінгу залізниць та запропоновано, здійснюючи структурне реформування української залізниці, орієнтуватись на гібридну (холдингову) модель анбандлінгу.

Проте, щоб Укрзалізниця мала незалежність та достатню кількість ресурсів щоб бути конкурентоспроможною, перелічених заходів, передбачених Законопроектом «Про залізничний транспорт України» від 06.09.2019 р. за №1196-1 (далі - Законопроект №1196-1), недостатньо. 
Для успішної реформи корпоративного управління Укрзалізниці необхідна чітка та послідовна візія, а також ефективне управління. Тож, Законопроект №1196-1 потребує на доповнення, зокрема, статтями, які передбачатимуть:

- механізм регулювання ринку приватної тяги;

- прозорий механізм тарифоутворення, модифікований шляхом розподілу залізничного тарифу на локомотивну, інфраструктурну та вагонну складову;

- механізм фінансування пасажирських перевезень;

- механізм створення Залізничного фонду та цільового використання його коштів.

Внесення зазначених доповнень до Законопроекту №1196-1 забезпечить ефективність анбандлінгу Укрзалізниці і відповідно прискорить розвиток мультимодальних перевезень та повноцінність використання мультимодального потенціалу України.

\section{Лimepamypa:}

1. Перевезення контейнерів територією України у 2020 році зросли майже на $11 \%$. URL: https://www.uz.gov.ua/press_center/up_to_date_topic/532811/

2. Укрзалізниця здійснюватиме контейнерні перевезення спільно 3 трьома єврокомпаніями. Укрінформ. URL: https://www.ukrinform.ua/rubric-economy/3129620ukrzaliznica-zdijsnuvatime-kontejnerni-perevezenna-spilno-z-troma-evrokompaniami.html

3. Про залізничний транспорт. Закон України від 31.10.2011 p. №9377. URL: https://zakon.rada.gov.ua/laws/show/273/96-\%D0\%B2\%D1\%80\#Text

4. Самойдюк М. (2019). Наглядова рада У3 переконана в необхідності анбандлінгу компанії та в перетворенні iï на холдинг. URL: https://www.railinsider.com.ua/naglyadova-rada-uz-perekonana-u-neobhi/

5. Пенькова К., Кривінчук Ю. та Прядко К. (2019). Моделі функціонування залізничних перевезень. Огляд іноземного досвіду. Інформаційна довідка, підготовлена Свропейським інформаційно-дослідницьким центром на запит народного депутата України. URL: http://euinfocenter.rada.gov.ua/uploads/documents/29219.pdf

6. Дейнека О.Г., Позднякова Л.О. Зарубіжний досвід реформування залізничного транспорту в контексті публічного управління та адміністрування Укрзалізниці. Вісник економіки транспорту та промисловості. 2012. № 37. С.148-152.

7. Любохинець Л.М. Реформування залізничного транспорту: досвід країн $\mathrm{CC.}$ Збірник наукових праиь Дніпропетровського наиіонального університету залізничного транспорту ім. академіка В. Лазаряна «Проблеми економіки транспорту». 2016. Вип. 12. C.77-83.

8. Прохорченко А. Досвід поступового підходу до впровадження рівноправного доступу у залізничній галузі Швеції. URL: http://www.railwayhub.in.ua/2018/02/blogpost.html\#: : :text=\%D0\%A3\%201988\%20\%D1\%80\%D0\%BE\%D1\%86

9. Веб-сторінка.SNCF. URL: https://www.sncf.com/en/group/profile-and-keyfigures/about-us/who-we-are

10. Польська стежка реформування. URL: http://zbk.org.ua/2016/11/22/polska-stezhkareformuvannya/

11. About PKP Energetyka. History. https://www.pkpenergetyka.pl/About-PKPEnergetyka/About-us/History-

12. Залізниці штатів очима російського мандрівника. залізниці сша: історія та опис загадка перших залізниць в Америці. URL: https://zizuhotel.ru/uk/life-hacks/zheleznyedorogi-shtatov-glazami-rossiiskogo-puteshestvennika/ 
13. Езугбая I. Як оптимізувати бізнес-процеси і вивести "Укрзалізницю" $з$ кризи. Економічна правда. URL: https://www.epravda.com.ua/columns/2021/03/11/671823/

14. Масько A.M. Реформування залізничного транспорту в Україні. Інфраструктура ринку. 2019. Вип. 33. С. 26-34.

15. Про залізничний транспорт України. Проект Закону України від 06.09.2019 р. за №1196-1. URL: https://w1.c1.rada.gov.ua/pls/zweb2/webproc4_1?pf3511=66737

16. Реформи залізничного транспорту. Міністерство інфраструктури України. URL: https://mtu.gov.ua/content/reformi-zaliznichnogo-transportu.html

17. Дергоусова А. О. Стратегічна модель розвитку залізничного транспорту України. Ефективна економіка. 2013. №2. URL: http://bit.ly/2rFNw5S.

18. Січкар Д. (2021). Бізнес очікує на реформу ринку залізничних перевезень. Європейська Бізнес Асоціація. URL: https://eba.com.ua/biznes-ochikuye-na-reformu-rynkuzaliznychnyh-perevezen/

\section{References:}

1. Perevezennia kontejneriv terytoriieiu Ukrainy u 2020 rotsi zrosly majzhe na $11 \%$ [Transportation of containers through the territory of Ukraine in 2020 increased by almost $11 \%$ ]. Sajt Ukrzaliznytsia - Sait Ukrzaliznytsia. Retrieved from https://www.uz.gov.ua/presscenter/ up_to_date_topic/532811/[in Ukrainian].

2. Ukrzaliznytsia zdijsniuvatyme kontejnerni perevezennia spil'no $\mathrm{z}$ tr'oma ievrokompaniiamy. [Ukrzaliznytsia will carry out container transportation together with three European companies]. Ukrinform - Ukrinform. Retrieved from https://www.ukrinform.ua/rubriceconomy/3129620-ukrzaliznica-zdijsnuvatime-kontejnerni-perevezenna-spilno-z-tromaevrokompaniami.html [in Ukrainian].

3. Zakon Ukrainy Pro zaliznychnyj transport : pryiniatyi 31 Oct 2011 roku № 9377 [Law of Ukraine About railway transport from October 31 2011, № 9377]. (n.d.). zakon.rada.gov.ua/laws/show. Retrieved from https://zakon.rada.gov.ua/laws/show/273/96$\%$ D0\%B2\%D1\%80\#Text [in Ukrainian].

4. Samoidyuk M. (2019). Nahliadova rada Ukrains'koi zaliznytsi perekonana v neobkhidnosti anbandlinhu kompanii ta v peretvorenni ii na kholdynh [The Supervisory Board of Ukrainian Railways is convinced of the need to unbundle the company and turn it into a holding company]. Retrieved from https://www.railinsider.com.ua/naglyadova-rada-uz-perekonana-uneobhi/ [in Ukrainian].

5. Penkova K., Kryvinchuk Yu. and Pryadko K. (2019). Modeli funktsionuvannia zaliznychnykh perevezen'. [Models of railway transportation functioning]. Ohliad inozemnoho dosvidu. Informatsijna dovidka, pidhotovlena Yevropejs'kym informatsijno-doslidnyts'kym tsentrom na zapyt narodnoho deputata Ukrainy - Review of foreign experience. Information reference prepared by the European Information and Research Center at the request of the People's Deputy of Ukraine. Retrieved from http://euinfocenter.rada.gov.ua/uploads/documents/ 29219.pdf [in Ukrainian].

6. Deyneka O.G. and Pozdnyakova L.O. (2012). Zarubizhnyj dosvid reformuvannia zaliznychnoho transportu v konteksti publichnoho upravlinnia ta administruvannia Ukrzaliznytsi. [Foreign experience of railway transport reform in the context of public administration and administration of Ukrzaliznytsia]. Visnyk ekonomiky transportu ta promyslovosti - Bulletin of Transport Economics and Industry, 37, 148-152 [in Ukrainian].

7. Lyubokhinets L.M. (2016). Reformuvannia zaliznychnoho transportu: dosvid krain Yevropejs'koho Soiuzu [Railway transport reform: the experience of EU countries]. Zbirnyk naukovykh prats' Dnipropetrovs'koho natsional'noho universytetu zaliznychnoho transportu im. akademika V. Lazariana "Problemy ekonomiky transportu»- Collection of scientific works of Dnipropetrovsk National University of Railway Transport. Academician V. Lazaryan "Problems of Transport Economics", 12, 77-83 [in Ukrainian].

8. Prokhorchenko A. (2018). Dosvid postupovoho pidkhodu do vprovadzhennia 
rivnopravnoho dostupu u zaliznychnij haluzi Shvetsii [Experience of a gradual approach to the introduction of equal access in the Swedish railway industry]. railwayhub.in.ua. Retrieved from http://www.railwayhub.in.ua/2018/02/blog-post.html\#: :text=\%D0\%A3\%201988\%20\%D1\% $80 \%$ [in Ukrainian].

9.Veb-storinka SNCF [Web page. SNCF]. sncf.com/en Retrieved from https://www.sncf.com/en/group/profile-and-key-figures/about-us/who-we-are [in Ukrainian].

10. Pol's'ka stezhka reformuvannia. [Polish path of reform]. (n.d.) zbk.org.ua. Retrieved from http://zbk.org.ua/2016/11/22/polska-stezhka-reformuvannya/ [in Ukrainian].

11. Veb-storinka History. About PKP Energetyka. [Web page. History. About PKP Energetyka] pkpenergetyka.pl. Retrieved from https://www.pkpenergetyka.pl/About-PKPEnergetyka/About-us/History-

12. Zaliznytsi shtativ ochyma rosijs'koho mandrivnyka. zaliznytsi ssha: istoriia ta opys zahadka pershykh zaliznyts' $\mathrm{v}$ Amerytsi. [The state railways through the eyes of a Russian traveler. US railways: history and description of the mystery of the first railroads in America]. . (n.d.). zizuhotel.ru. Retrieved from https://zizuhotel.ru/uk/life-hacks/zheleznye-dorogi-shtatovglazami-rossiiskogo-puteshestvennika/ [in Ukrainian].

13. Ezugbaya I. (2021). Yak optymizuvaty biznes-protsesy i vyvesty "Ukrzaliznytsiu" z kryzy. [How to optimize business processes and bring Ukrzaliznytsia out of the crisis]. Ekonomichna Pravda - Economic truth. Retrieved from https://www.althoughda.com.ua/ columns/ 2021/03/11/671823/ [in Ukrainian].

14. Masko A.M. (2019). . Reformuvannia zaliznychnoho transportu v Ukraini [Reform of railway transport in Ukraine. Infrastruktura rynku - Market infrastructure, 33. 26-34. [in Ukrainian].

15. Proekt Zakonu Ukrainy Pro zaliznychnyj transport Ukrainy. 06. Sep. 2019 roku №1196-1. [Draft Law of Ukraine About railway transport of Ukraine] (2019, September 6). Retrieved from https://w1.c1.rada.gov.ua/pls/zweb2/webproc4_1?pf3511=66737 [in Ukrainian].

16. Veb-storinka Ministerstvo infrastruktury Ukrainy «Reformy zaliznychnoho transportu». [Railway transport reforms]. (n.d.). (n.d.). mtu.gov.ua. Retrieved from https://mtu.gov.ua/content/reformi-zaliznichnogo-transportu.html [in Ukrainian].

17. Dergousova A.A. (2013). Stratehichna model' rozvytku zaliznychnoho transportu Ukrainy [Strategic model of railway transport development of Ukraine]. Efektyvna ekonomika Efficient economy. 2, Retrieved from http://bit.ly/2rFNw5S [in Ukrainian].

18. Sichkar D. (2021). Biznes ochikuie na reformu rynku zaliznychnykh perevezen'.[Business is waiting for the reform of the railway market]. Yevropejs'ka Biznes Asotsiatsiia - European Business Association. Retrieved from https://eba.com.ua/biznesochikuye-na-reformu-rynku-zaliznychnyh-perevezen/ [in Ukrainian]. 